\title{
THE DIFFICULTY OF Constitutional Amendment in CANAdA
}

\author{
RICHARD ALBERT ${ }^{*}$
}

\begin{abstract}
Scholars of comparative constitutional law would suggest that the United States Constitution is the world's most difficult democratic constitution to change by formal amendment. This article suggests that the Constitution of Canada may be even harder to amend. Canadian constitutional politics have proven the textual requirements for major constitutional amendment so far impossible to satisfy. But the extraordinary difficulty of formal amendment in Canada derives equally from sources external to the text. Major constitutional amendment also requires conformity with extra-textual requirements imposed by Supreme Court decisions interpreting the Constitution of Canada, parliamentary and provincial as well as territorial statutes, and arguably also by constitutional conventions - additional rules that may well make major constitutional amendment impossible today in Canada. These as yet underappreciated extra-textual sources of formal amendment difficulty raise important questions for Canadian constitutionalism, namely whether in making the Constitution virtually impossible to amend they weaken democracy and undermine the purpose of writtenness.
\end{abstract}

\section{TABLE OF CONTENTS}

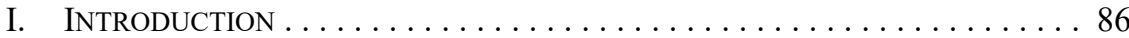

II. Formal AMENDMENT RULES IN DEMOCRATIC CONSTITUTIONS . . . . . . . 89

A. Studies of AmENDMENT DifFiculty $\ldots \ldots \ldots \ldots \ldots \ldots$

B. Rigid CONSTitutions AND their AMENDMENT Rules $\ldots . \ldots \ldots 92$

C. Formal AMENDMENT Rules In CANADA . . . . . . . . . . . . 93

III. EXTRA-TEXTUAL AMENDMENT Rules IN CANADA $\ldots \ldots \ldots \ldots \ldots \ldots$

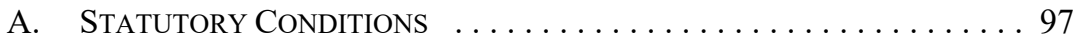

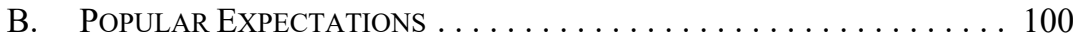

C. Judicial STANDARDS $\ldots \ldots \ldots \ldots \ldots \ldots \ldots \ldots \ldots \ldots \ldots \ldots \ldots \ldots$

IV. Canadian Constitutionalism and Formal Amendment . . . . . . 105

A. DEMOCRACY AND AMENDMENT $\ldots \ldots \ldots \ldots \ldots \ldots \ldots \ldots \ldots$

B. ThE WEAKENING OF WritTENNESS . . . . . . . . . . . . . 107

C. FORMAL AMENDMENT RULES

AND THE VALUE OF WRITTENNESS $\ldots \ldots \ldots \ldots \ldots \ldots \ldots \ldots$

V. CONCLUSION ............................ 112

Associate Professor, Boston College Law School; Visiting Associate Professor of Law and Canadian Bicentennial Visiting Associate Professor of Political Science, Yale University (2015-16); Yale University (BA, JD); Oxford University (BCL); Harvard University (LLM). Email: richard.albert@ bc.edu. I have benefitted from comments on earlier drafts of this article from Farrah Ahmed, Joel ColónRíos, Xenophon Contiades, Hoi Kong, Ronald Krotoszynski, Derek O’Brien, Adam Perry, Peter Russell, and the three anonymous reviewers, commissioned by the Alberta Law Review, who recommended this article for publication. I have also received useful suggestions in the course of presentations at Boston College, McGill University, Queen's University, the University of Ottawa, and the University of Oxford. My thanks to the Boston College Law School Fund for so generously supporting my scholarly research. 


\section{INTRODUCTION}

The United States Constitution is widely regarded as one of the world's most difficult democratic constitutions to change by a formal constitutional amendment. ${ }^{1}$ Formal amendment in the United States requires two-thirds agreement in both houses of Congress to propose an amendment and the approval of three-quarters of the states to ratify it. ${ }^{2}$ As hard as it may have been at the founding to assemble those supermajorities among 59 Representatives, 20 Senators, 13 states and no political parties, ${ }^{3}$ it is much harder today with 435 Representatives, 100 Senators, 50 states, and hyper-partisan political parties. ${ }^{4}$ Perhaps the best illustration of the difficulty of formal amendment in the US is the historical rate of amendment failure: of the more than 11,000 amendments proposed since 1789, only 27 have been ratified, ${ }^{5}$ an astonishingly low number by comparison with modern constitutional democracies. ${ }^{6}$ Scholars have therefore suggested that the US Constitution may today very well be impossible to change by formal amendment. ${ }^{7}$

No one can deny the difficulty of amending the US Constitution. But the Constitution of Canada may be even harder to amend. The principal source of amendment difficulty is the Constitution Act, 1982, which creates an onerous escalating structure of five formal amendment rules that impose increasingly demanding thresholds, ${ }^{8}$ each of which is keyed to specific constitutional commitments. ${ }^{9}$ Modern constitutional politics are an additional source of amendment difficulty. The failure of the Meech Lake and Charlottetown Accords has proven major constitutional amendments so far impossible to achieve, ${ }^{10}$ and the prevailing culture of major amendment failure may dissuade political actors from undertaking

See e.g. Sanford Levinson, Our Undemocratic Constitution: Where the Constitution Goes Wrong (and How We the People Can Correct It) (New York: Oxford University Press, 2006) at 21; Donald S Lutz, Principles of Constitutional Design (New York: Cambridge University Press, 2006) at 170 [Lutz, Constitutional Design]; Dieter Grimm, "Types of Constitutions" in Michel Rosenfeld \& András Sajó, eds, The Oxford Handbook of Comparative Constitutional Law (Oxford: Oxford University Press, 2012) 98 at 111; Mark Tushnet, "Marbury v. Madison Around the World" (2004) 71:2 Tenn L Rev 251 at 260, n 36.

US Const art V. The Constitution also authorizes amendment by constitutional convention in a special assembly convened for that purpose, but this convention process has never been successfully used. See William B Fisch, "Constitutional Referendum in the United States of America" (2006) 54:Supp Am J Comp L 485 at 490.

Eric Posner, "The U.S. Constitution Is Impossible to Amend," Slate.com (5 May 2014), online: <www. slate.com/articles/news_and_politics/view_from_chicago/2014/05/amending_the_constitution_is _ much too_hard_blame_the founders.html $>$.

See Richard Albert, "Constitutional Disuse or Desuetude: The Case of Article V" (2014) 94:3 BUL Rev 1029 at 1048-51 [Albert, "Constitutional Disuse"].

Kathleen M Sullivan, "Constitutional Constancy: Why Congress Should Cure Itself of Amendment Fever" (1996) 17:3 Cardozo L Rev 691 at 692.

6 For example, as of 2013, the Indian Constitution had been formally amended 98 times since coming into force in 1950 and the South African Constitution has already been formally amended 17 times since its adoption in 1996.

7 See e.g. Richard H Fallon, Jr, "Constitution Day Lecture: American Constitutionalism, Almost (But Not Quite) Version 2.0" (2012) 65:1 Me L Rev 77 at 92; Henry Bournes Higgins, "The Rigid Constitution" (1905) 20:2 Political Science Q 203 at 210; Miguel Schor, "Judicial Review and American Constitutional Exceptionalism" (2008) 46:3 Osgoode Hall LJ 535 at 540.

$8 \quad$ Procedure for Amending Constitution of Canada, Part V of the Constitution Act, 1982, being Schedule B to the Canada Act 1982 (UK), 1982, c 11 [Constitution Act, 1982].

9 For a comparative analysis of Canada's escalating structure of formal amendment rules, see Richard Albert, "The Structure of Constitutional Amendment Rules" (2014) 49:4 Wake Forest L Rev 913.

10 See 1987 Constitutional Accord, Schedule to Constitutional Amendment, 1987 (3 July 1987) [Meech Lake Accord]; Consensus Report on the Constitution (Charlottetown, 28 August 1992) [Charlottetown Accord]. 
similarly grand efforts at constitutional renewal. ${ }^{11}$ But another source of amendment difficulty remains underappreciated.

The extraordinary difficulty of formal amendment in Canada derives equally from sources external to the Constitution's formal amendment rules. The supermajority and federalist thresholds entrenched in the Constitution Act, 1982 are demanding on their own, but major constitutional amendment now also requires conformity with extra-textual requirements imposed by Supreme Court decisions interpreting the Constitution of Canada, parliamentary and provincial as well as territorial statutes, and arguably also by constitutional conventions, which refer to the unwritten yet binding constitutional norms that develop in the course of constitutional politics. These extra-textual requirements for formal amendment appear nowhere in the text of the Constitution Act, 1982, but they are perhaps just as significant as the ones that do. Uncodified, though broadly recognized as valid, they so exceedingly complicate the process of formal amendment that we might more accurately speak of amendment impossibility in Canada rather than mere difficulty.

Of course, Canada is not the only country whose formal amendment rules are susceptible to informal modification by judicial interpretation, legislative or executive action, and constitutional convention. Indeed, my current research concerns the identification and evaluation of a global trend in the informal modification of formal amendment rules. The most well-known manifestation of informal changes to formal amendment rules is the judicial creation of the basic structure doctrine, most commonly associated with the Indian Supreme Court. ${ }^{12}$ The Court has developed, in the course of its common law constitutional interpretation, a theory of the implicit unamendability of certain constitutive features of the "basic structure" of the Indian Constitution, namely federalism, the separation of powers, and secularism. ${ }^{13}$ The consequence of the basic structure doctrine has been to impose courtcreated limits on the textually unlimited power of political actors to formally amend the Indian Constitution. ${ }^{14}$ India, then, demonstrates the phenomenon I explore in this article. Nonetheless, this phenomenon - the development of extra-textual rules governing formal amendment - is most apparent to me in its richness and complexity in Canada, where it derives not only from judicial interpretation as in India, but also from legislation, executive action, and convention. Canada therefore offers a valuable case study to illustrate how this phenomenon arises.

In this article, I suggest that major constitutional amendment to the Constitution of Canada may today be so difficult as to render it impossible. Although I make some empirical comparisons, this article is not principally an empirical inquiry in amendment difficulty

11 Ronald L Watts, “Canada: Three Decades of Periodic Federal Crises” (1996) 17:4 Intl Political Science Rev 353 at 368 .

12 For a description of the basic structure doctrine, see Richard Albert, "The Unamendable Core of the United States Constitution" in András Koltay, ed, Comparative Perspectives on the Fundamental Freedom of Expression [forthcoming in 2015], online: <ssrn.com/abstract=2601646>; Sudhir Krishnaswamy, Democracy and Constitutionalism in India: A Study of the Basic Structure Doctrine (Oxford: Oxford University Press, 2010).

13 See Kesavananda Bharati v Kerala, [1973] 4 SCC 225 (India) at para 316, online: <www.indiankanoon. org/doc/25787617> at para 316. But the Court has been "deliberately vague about exactly what counts as part of that 'basic structure"”: Pratap Bhanu Mehta, "The Rise of Judicial Sovereignty" (2007) 18:2 J Democracy 70 at 76.

14 The Indian Constitution establishes no subject matter constraints on formal amendment. See India Const, pt XX, art 368 (1950). 
largely because, as I will explain below, ${ }^{15}$ empirical studies of amendment difficulty pose analytical challenges that neither I nor indeed others are yet fully equipped to overcome. I instead draw from existing empirical studies to explore in comparative perspective the difficulty of major constitutional amendment in Canada in light of both the codified and uncodified rules of formal amendment. I begin, in Part II, by situating the difficulty of Canada's formal amendment rules among amendment rules in other democratic constitutions. In Part III, I explain and evaluate how political actors have created extra-textual amendment rules that now exacerbate the difficulty of Canada's already onerous formal amendment rules. In Part IV, I offer brief reflections on whether these extra-textual foundations of formal amendment difficulty are problematic for Canadian constitutionalism. I suggest that these extra-textual restrictions undermine the exercise of democracy and transform the written constitution into an incomplete code for the accomplishment of a task that is by definition rooted in textual authority.

First, however, by way of introduction, I define two important terms. I am concerned in this article with the possibility of major reforms to the framework and identity of the state, what I refer to in this paper as "major constitutional amendments" to the Constitution of Canada. I define this to mean what Peter Russell understood as the kinds of changes achievable only through "mega constitutional politics," which is to say those changes that "address the very nature of the political community on which the constitution is based," that have a "tendency to touch citizens' sense of identity and self-worth," and that are "concerned with reaching agreement on the identity and fundamental principles of the body politic."16 These kinds of amendments are possible only with the default multilateral and unanimity amendment procedures in the Constitution of Canada. ${ }^{17}$ These two onerous thresholds have been satisfied collectively only once since they came into force over three decades ago. ${ }^{18}$ The rest of Canada's ten formal amendments - as of 2015, there have been a total of eleven have occurred using the Constitution's other formal amendment procedures,${ }^{19}$ each of which demands considerably lower thresholds of political agreement for their successful use. ${ }^{20}$ Below, I discuss in detail the five formal amendment procedures open to political actors. ${ }^{21}$

Second, I focus in this article on why it is so difficult to formally amend the Constitution of Canada. Formal amendment refers to textual alterations to the Constitution. I do not inquire in this article into the relative ease or difficulty of informal amendment, which occurs

15 See Part II.A, below.

16 See Peter H Russell, Constitutional Odyssey: Can Canadians Become a Sovereign People?, 3rd ed (Toronto: University of Toronto Press, 2004) at 75.

17 As I discuss in Part II.C below, the Constitution of Canada entrenches five formal amendment procedures. Each may be used on its own to make important changes to the Constitution, and indeed most of the changes to the codified Constitution of Canada have occurred using neither the default multilateral amendment procedure nor the unanimity procedure. Nonetheless, I focus in this article on those two formal amendment procedures because they are the ones that best reflect the Constitution of Canada's recognition of the possibility of major constitutional amendment.

18 See Peter W Hogg, Constitutional Law of Canada, 5th ed (Toronto: Carswell, 2007) (loose-leaf updated 2014, release 1) vol $1 \mathrm{ch} 1$ at 1-7-1-8, n 32.

19 See Ian Greene, "Constitutional Amendment in Canada and the United States" in Stephen L Newman, ed, Constitutional Politics in Canada and the United States (Albany: State University of New York Press, 2004) 249 at 254. Ibid.

See Part II.C, below. 
when the Constitution changes in meaning without a corresponding alteration to its text. ${ }^{22} \mathrm{I}$ have written elsewhere in detail about this phenomenon of informal amendment with particular respect to Canada, ${ }^{23}$ where admittedly the Constitution has changed informally more frequently than formally. ${ }^{24}$ Informal amendment is of course at the core of constitutional change in Canada. But it is precisely because of the infrequency of formal amendment that it is important to separate formal from informal amendment - in order to understand why the former is today less likely than the latter, and indeed perhaps impossible under the current structure of formal amendment in Canada.

\section{Formal Amendment Rules in Democratic Constitutions}

The study of comparative amendment difficulty could conceivably lend itself well to empirical analysis. We could, for example, compare the number of amendments across jurisdictions, noting that the US Constitution has been amended 27 times since its cominginto-force in 1789 as compared to 11 times in Canada since the entrenchment of its modern constitutional text in $1982 .{ }^{25}$ But this comparative exercise would help us track amendment frequency, not necessarily amendment difficulty. We could alternatively compare thresholds for formal amendment. But it is not clear that the three-quarters threshold for state ratification in the US is harder to satisfy than the default multilateral amendment procedure in Canada. ${ }^{26}$

The point is that measuring amendment difficulty is itself a difficult task. ${ }^{27}$ Voting thresholds for proposing and ratifying a formal amendment are important to the study of amendment difficulty, but what may matter more is the amendment culture in a constitutional tradition, meaning how often and successfully amendment has been contemplated and ultimately pursued. ${ }^{28}$ The contours of the national culture of amendment may also change over time as political actors, institutions, and the people grow more or less amenable to the high costs of undertaking to change their constitution. What is more, measuring amendment

Heather K Gerken, "The Hydraulics of Constitutional Reform: A Skeptical Response to Our Undemocratic Constitution" (2007) 55:4 Drake L Rev 925 at 929. For useful reflections on the challenge of identifying amendment-level changes, see Sanford Levinson, "How Many Times Has the United States Constitution Been Amended? (A) <26; (B) 26; (C) 27; (D) >27: Accounting for Constitutional Change' in Sanford Levinson, ed, Responding to Imperfection: The Theory and Practice of Constitutional Amendment (Princeton: Princeton University Press, 1995) at 25-26 [Levinson, Responding to Imperfection].

23 See generally Richard Albert, "Constitutional Amendment by Stealth" 60 McGill LJ [forthcoming in 2015] (evaluating constitutional amendment by convention); Richard Albert, "Amending Constitutional Amendment Rules" 13 Intl J Const L [forthcoming in 2015] (discussing constitutional amendment by convention); Richard Albert, "Constitutional Amendment by Constitutional Desuetude"(2014) 62:3 Am J Comp L 641 [Albert, "Constitutional Desuetude"] (theorizing constitutional amendment by convention); Richard Albert, "Constructive Unamendability in Canada and the United States" (2014) 67 SCLR (2d) 181 [Albert, "Constructive Unamendability"] (examining the relationship between constitutional rigidity and constitutional amendment by convention). For a discussion of the forms of informal amendment in the US, see Albert "Constitutional Disuse," supra note 4 at 1060-71.

24 See Allan C Hutchinson, "Constitutional change and constitutional amendment: A Canadian codundrum" in Xenophon Contiades, ed, Engineering Constitutional Change: A Comparative Perspective on Europe, Canada and the USA (Abington: Routledge, 2013) 51 at 57-70.

25 Hogg, supra note 18 , ch 1 at 1-7-1-8, n 32

26 Compare US Const art V, supra note 2 with Constitution Act, 1982, supra note 8, s 38. I explain in Part II.C, below, what the default multilateral amendment procedure is and why we can properly describe it as Canada's "default" amendment rule.

27 Tom Ginsburg \& James Melton, "Does the Constitutional Amendment Rule Matter at All? Amendment Cultures and the Challenges of Measuring Amendment Difficulty" 13 Intl J Const L [forthcoming in 2015].

28 Ibid. 
culture - if one can reliably identify $\mathrm{it}^{29}$ — is complicated even further by variations in amendment cultures within federal systems: subnational states might differ both from the national state and among themselves in their inclination to undertake a national-scale amendment. ${ }^{30}$ It is therefore difficult to conclude with any confidence that one constitution is harder to amend than another on the basis of the voting thresholds alone. ${ }^{31}$

\section{A. Studies of Amendment Difficulty}

What makes this comparative inquiry particularly challenging with respect to Canada is the difficulty of identifying what precisely constitutes an amendment. The definition of a formal amendment - an alteration to the constitutional text ${ }^{32}$ - maps comfortably onto a master-text constitutional regime governed under a codified constitution. But Canada does not have a master-text constitution. It has a partially written and unwritten constitution that operates differently from the conventional model of a master-text regime like the US. Some parts of the Constitution of Canada are codified - making it seem like a master-text constitutional regime - but others are written yet disaggregated, and still others are altogether unwritten. This makes it hard to identify the complete universe of what possesses constitutional status, and in turn to identify when a change requires recourse to the procedures of formal amendment. ${ }^{33}$

The codified Constitution of Canada both clarifies and complicates this conceptual challenge. It clarifies some questions by identifying what counts as "constitutional" in Canada. The Constitution Act, 1982 entrenches a list of the items that comprise the Constitution of Canada. ${ }^{34}$ But this clarification is also a complication because the very same list suggests that it is a non-exhaustive enumeration. The key word, reproduced below from the text of the Constitution Act, 1982 is "includes," which suggests that other items do indeed qualify as part of the Constitution of Canada but are just not listed in its text:

(2) The Constitution of Canada includes

(a) the Canada Act 1982, including this Act;

(b) the Acts and orders referred to in the schedule; and

(c) any amendment to any Act or order referred to in paragraph (a) or (b). ${ }^{35}$

See Christopher L Eisgruber, Constitutional Self-Government (Cambridge, MA: Harvard University Press, 2001) at 22.

$30 \quad$ Ginsburg \& Melton, supra note 27.

31 For example, in his classification scheme, one scholar suggests, though does not state, that the Australian and Canadian Constitutions are similarly difficult to amend given that they both (sometimes) require a simple legislative vote followed by approval by provincial assemblies, and that both are easier as compared to the US Constitution, which requires two-thirds legislative vote followed by three-quarters ratification by the states. See Edward Schneier, Crafting Constitutional Democracies: The Politics of Institutional Design (Lanham: Rowman \& Littlefield, 2006) at 224-25. But how can we be certain that any of these three constitutions is harder or easier to amend than the South African Constitution, which (sometimes) requires a three-fourths legislative vote and majority approval by the provinces, or even the Eritrean Constitution, which requires a three-fourths legislative vote and a further four-fifth legislative vote one year later (ibid at 225). Knowing as a certainty requires some demonstrated insights drawn from analyses of several indicators, including political culture, legislative capacity, party politics, historical amendability, rates of popular participation, and the effectiveness of the separation of powers. See Part I, above. Note furthermore that my focus in this article is on the difficulty of major formal amendment.

See Lutz, Constitutional Design, supra note 1 at 179-80, n 16.

See Constitution Act, 1982, supra note 8, s 52(2).

Ibid. 
The "Constitution of Canada" of course also includes the preambular declarations of values and other commitments in the Constitution Acts, 1867 to 1982, namely the preambular statement in the Constitution Act, 1867, which states in part that Canada shall have "a Constitution similar in Principle to that of the United Kingdom." ${ }^{36}$ How are we to identify a formal amendment to this preambular value ${ }^{37}$ As I suggest in the pages below, the indeterminacy of the identity, scope, and meaning of Canada's unwritten constitutional principles is itself a source of formal amendment difficulty insofar as it shifts to the judiciary the responsibility to identify what is amendable and how - that is to say, according to which of Canada's five formal amendment procedures. ${ }^{38}$ Notwithstanding this conceptual challenge to defining the boundaries of amendment in Canada and in other states without a master-text constitution, scholars have measured amendment difficulty across jurisdictions.

Donald Lutz has produced the leading study of comparative amendment difficulty. ${ }^{39}$ Lutz endeavours to quantify the difficulty of each discrete step in an amendment process in order to estimate the relative difficulty of whole amendment processes. Lutz identifies 68 possible steps in an amendment process, for instance initiation by a specially appointed body or ratification by referendum requiring an absolute majority. ${ }^{40}$ Aggregating the scores for each of 36 democratic countries in his study sample - Lutz does not rank Canada because of his stated difficulty in determining what has constitutional status ${ }^{41}$ — he concludes that the US Constitution (5.10) ranks as the most rigid, followed by Switzerland (4.75) and Venezuela (4.75), then Australia (4.65), Costa Rica (4.10), Spain (3.60) and Italy (3.40). ${ }^{42}$ Lutz finds that New Zealand (0.50) has the easiest "constitution" to amend, ${ }^{43}$ which makes sense given that it is closest to a model of pure parliamentary sovereignty where changes occur by simple legislative vote. ${ }^{44}$

There are other scholarly studies of amendment difficulty. Astrid Lorenz has designed her own scale to measure 39 stable democracies and concluded that Belgium (9.5) has the highest index of amendment difficulty, followed closely by the US (9.0) and Bolivia (9.0), and then the Netherlands (8.5). ${ }^{45}$ The next three hardest-to-amend are tied (8.0): Australia, Denmark and Japan. ${ }^{46}$ Canada (7.0) is next, tied with Chile and Switzerland. The easiest constitutions to amend on her scale are the constitutions of the UK (1.0) and New Zealand

Constitution Act, 1867 (UK), 30 \& 31 Vict, c 3, preamble, reprinted in RSC 1985, Appendix II, No 5. The value commitment reflected in the "Similar-in-Principle" Clause was superseded at least in part when a majority of Canadian political actors agreed to the Constitution Act, 1982, in so doing transforming Canada into a model of constitutional sovereignty rooted in institutional roles inconsistent with the model of parliamentary sovereignty that existed in the UK at that time. See Richard Albert, "Advisory Review: The Reincarnation of the Notwithstanding Clause" (2008) 45:4 Alta L Rev 1037 at $1048-50$.

For a detailed discussion of these five amendment procedures, see Part II.C, below.

Lutz, Constitutional Design, supra note 1

Ibid at $167-68$.

Ibid at $179-80$, n 16.

Ibid at 170 .

It is unusual to refer to the "New Zealand Constitution," since it might suggest exclusive reference to the Constitution Act 1986, which forms only part of New Zealand's "constitution," much of which is both written and unwritten, and therefore not codified in a master-text. Nonetheless, I refer to New Zealand as having an amendable constitution in order to track Lutz's own study of amendability in New Zealand. See ibid at $125,170,177$.

Ibid at $170,177$.

Astrid Lorenz, "How to Measure Constitutional Rigidity: Four Concept and Two Alternatives" (2005) 17:3 J Theoretical Politics 339 at 358-59.

Ibid. 
(1.0) ${ }^{47}$ For his part, Arend Lijphart has evaluated how 36 democracies operationalize formal amendment in terms of their required majorities. Lijphart ranked seven constitutions in the top group (4.0) of amendment difficulty given their requirement of super-majorities greater than two-thirds: Argentina, Australia, Canada, Germany, Japan, Korea, Switzerland and the US. ${ }^{48}$ Germany (3.5) ranks immediately behind, followed by 15 countries tied (3.0) in light of their two-thirds requirement or its equivalent. ${ }^{49}$ The next group of eight countries (1.5 to 2.0) requires something between an ordinary majority and two-thirds majorities. The last group, requiring only ordinary majorities (1.0), includes five countries. ${ }^{50}$

\section{B. Rigid CONSTITUTIONS AND THEIR AMENDMENT RULES}

In their comparative studies of amendment difficulty, scholars have identified certain features associated with greater rigidity than flexibility. ${ }^{51}$ Lutz, for example, assigns the highest level of amendment difficulty to procedures that require a petition signed by more than 500,000 voters to initiate an amendment or to those that condition ratification on unanimous approval by subnational governments. ${ }^{52}$ The next most difficult amendment feature requires ratification by a majority of voters and a majority of states. ${ }^{53}$ Lutz also assigns high measures of difficulty to procedures requiring two separate two-thirds votes in a bicameral legislature in order to either initiate or ratify an amendment, three-quarters votes among subnational legislatures or conventions to initiate or ratify an amendment, and a petition signed by $250,000-500,000$ voters to initiate an amendment. ${ }^{54}$ In contrast, Lutz assigns the lowest level of difficulty to amendment procedures requiring executive action alone to initiate an amendment, one-third or fewer votes in a specially constituted body to ratify an amendment, one-third majority or less in a unicameral legislature to ratify an amendment, or an election between two votes to either initiate or ratify an amendment. ${ }^{55}$

We can calculate how Lutz arrived at the specific scores for the constitutions in his study sample. Take for example, the US Constitution, which scored 5.10, the highest total, for constitutional rigidity. Under Article V, which entrenches the amending clause in the US Constitution, the bicameral Congress must vote by two-thirds to initiate an amendment, ${ }^{56} \mathrm{a}$ process that is worth 1.60 points toward the entire score. Next, a successful Article V amendment requires at least three-quarters of the states to ratify the initiated amendment, a

Ibid.

Arend Lijphart, Patterns of Democracy (New Haven: Yale University Press, 2012) at 208.

Ibid.

Ibid.

Lijphart focuses his own analysis on the quantum of legislative agreement - ranging from super- to ordinary majorities - required to approve an amendment. See text accompanying notes 48-50, above. Lutz, Constitutional Design, supra note 1 at 167-68.

Ibid at 168 .

Ibid at $167-68$.

Ibid. See text accompanying notes 39-42, above.

US Const art V, supra note 2 :

The Congress, whenever two-thirds of both Houses shall deem it necessary, shall propose Amendments to this Constitution, or, on the Application of the Legislatures of two-thirds of the several States, shall call a Convention for proposing Amendments, which, in either Case, shall be valid to all Intents and Purposes, as part of this Constitution, when ratified by the Legislatures of three-fourths of the several States, or by Conventions in three-fourths thereof, as the one or the other Mode of Ratification may be proposed by the Congress; Provided that no Amendment which may be made prior to the Year One thousand eight hundred and eight shall in any Manner affect the first and fourth Clauses in the Ninth Section of the first Article; and that no State, without its Consent, shall be deprived of its equal Suffrage in the Senate. 
step that counts for 3.50 points. The sum of both parts of this Article V process is therefore $5.10 .{ }^{57}$ We can work through the same calculation for Japan, for instance, ${ }^{58}$ which scored 3.10 on Lutz's index of amendment difficulty. This score is the sum of the value assigned to initiating an amendment by two-thirds majority in the bicameral Diet (1.60) and ratifying it in a referendum requiring a majority vote $(1.50) .{ }^{59}$ Similarly, the process of amending the New Zealand constitution, whose score on his index of amendment difficulty is 0.50 , requires only a majority vote in the unicameral legislature, a procedure Lutz values at $0.50 .^{60}$

\section{Formal Amendment Rules in CANAdA}

The formal amendment rules entrenched in the Constitution of Canada reflect many of the features that, either by causation or correlation, are associated with amendment difficulty. Lutz does not include Canada in his study sample but, had he measured its amendment difficulty, he might have found that it ranks near or above the United States in constitutional rigidity. The problem, however, would be where to start, since the Constitution of Canada entrenches five formal amendment procedures, each useable only in connection with specific items. $^{61}$

Consider first the default multilateral amendment procedure in section $38 .{ }^{62}$ This procedure has been successfully used only once. ${ }^{63}$ It requires approval from both houses of Parliament as well as from at least two-thirds of the provinces representing at least half of the total provincial population. ${ }^{64}$ This procedure is expressly identified as the "general" default procedure to amend all provisions and principles not otherwise entrenched under one of Canada's four other amendment thresholds, and it also serves as the designated threshold for specifically enumerated items, including provincial representation in the Senate, senatorial powers and elections, and the creation of new provinces. ${ }^{65}$ Under Lutz's index, Canada's default multilateral amendment procedure would score 4.50, the sum of 1.00 for parliamentary approval and 3.50 for provincial approval, ${ }^{66}$ good for fourth on his ranking of amendment difficulty.

Lutz, Constitutional Design, supra note 1 at 169.

Japan Const, ch IX, art 96 (1947):

Amendments to this Constitution shall be initiated by the Diet, through a concurring vote of twothirds or more of all the members of each House and shall thereupon be submitted to the people for ratification, which shall require the affirmative vote of a majority of all votes cast thereon, at a special referendum or at such election as the Diet shall specify.

Amendments when so ratified shall immediately be promulgated by the Emperor in the name of the people, as an integral part of this Constitution.

Lutz, Constitutional Design, supra note 1 at 167-68.

Ibid at 168 .

See Constitution Act, 1982, supra note 8, ss 38-49.

Ibid, s 38(1):

An amendment to the Constitution of Canada may be made by proclamation issued by the Governor General under the Great Seal of Canada where so authorized by $(a)$ resolutions of the Senate and House of Commons; and $(b)$ resolutions of the legislative assemblies of at least twothirds of the provinces that have, in the aggregate, according to the then latest general census, at least fifty per cent of the population of all the provinces.

Note that a province may, in certain circumstances, opt-out of an amendment adopted using the general procedure: see ibid, s 38(3).

See Constitutional Amendment Proclamation, 1983, SI/84-102, (1984) C Gaz II, 2984; see also Hogg, supra note 18 , ch 1 at 1-7-1-8 (cataloguing all constitutional amendments).

Constitution Act, 1982, supra note 8, s 38(1).

Ibid, s 42(1).

It is important to note that the default multilateral amendment procedure may be initiated by either of the two houses of Parliament or by the legislative assembly of a province: ibid, s 46(1). 
But Lutz's index does not account for alternative amendment thresholds nor does it incorporate escalating amendment thresholds. The US Constitution, for instance, entrenches an alternative amendment threshold requiring two-thirds of state legislatures to petition Congress to call a constitutional convention where amendments will be proposed and thereafter ratified by two-thirds of state legislatures. ${ }^{67}$ This alternative amendment threshold would score 6.50 on Lutz's scale, by far the highest of all national constitutions in his sample. ${ }^{68}$ Yet because the US has never used this procedure, ${ }^{69}$ Lutz does not measure it. He instead determines that "we can use the lower figure unless or until the more difficult procedure is ever used."70 This choice obscures the possibility that the non-use of this alternative amendment threshold may itself be the consequence of its perceived amendment difficulty.

The choice to exclude alternative amendment thresholds has implications for measuring amendment difficulty in Canada. Like the US, Canada entrenches alternative amendment thresholds, though it does so in a larger structure of escalating amendment rules, which assigns thresholds of increasing difficulty according to the importance of the entrenched constitutional provision or principle. ${ }^{71}$ Thus, alongside the default multilateral amendment threshold, which is itself difficult to satisfy, Canada entrenches an even harder threshold requiring approval in both houses of Parliament and from each provincial assembly. ${ }^{72}$ This unanimity procedure has not once been successfully used since it was entrenched in the Constitution Act, 1982. Political actors must satisfy this procedure to amend the most important provisions and principles in the Constitution of Canada, including its structure of formal amendment rules and the monarchy, as well as provincial representation in the House of Commons and the Senate, the use of English or French, and the composition of the Supreme Court of Canada, the last three subject to related but lesser matters amendable by another specially designated lower threshold..$^{73}$ On Lutz's scale, this unanimity threshold would score 5.00 for amendment difficulty: the sum of 1.00 for parliamentary approval and 4.00 for unanimous provincial approval. This would place Canada at a very close second to the US on Lutz's index of difficulty.

Yet the structure of Canada's formal amendment rules is even more complicated than the default multilateral and unanimity procedures suggest. The escalating structure of formal amendment creates three more amendment thresholds, for a total of five. The Constitution of Canada entrenches a narrow federal unilateral amendment procedure in section 44

\section{US Const art V.}

Lutz, Constitutional Design, supra note 1 at 169.

See Fisch, supra note 2 at 490.

Lutz, Constitutional Design, supra note 1 at 169.

For an analysis of the expressive purpose of escalating amendment thresholds in Canada, see Richard Albert, "The Expressive Function of Constitutional Amendment Rules" (2013) 59:2 McGill LJ 225 at $247-51$.

Constitution Act, 1982, supra note 8, s 41:

An amendment to the Constitution of Canada in relation to the following matters may be made by proclamation issued by the Governor General under the Great Seal of Canada only where authorized by resolutions of the Senate and House of Commons and of the legislative assembly of each province: ( $a$ ) the office of the Queen, the Governor General and the Lieutenant Governor of a province; (b) the right of a province to a number of members in the House of Commons not less than the number of Senators by which the province is entitled to be represented at the time this Part comes into force; (c) subject to section 43, the use of the English or the French language; $(d)$ the composition of the Supreme Court of Canada; and $(e)$ an amendment to this Part. Ibid. 
authorizing Parliament to amend its internal constitution and matters of federal executive government. ${ }^{74}$ Political actors may not use this procedure to amend matters expressly assigned to another, more difficult, amendment procedure. ${ }^{75}$ Since the entrenchment of the Constitution Act, 1982, this federal unilateral amendment procedure has been used three times. $^{76}$

The Constitution also entrenches a regional amendment procedure, which requires both houses of Parliament and the assemblies of one or more provinces affected by a given amendment each to agree by majority resolution to the amendment. ${ }^{77}$ This procedure may be used only for regional matters whose subject concerns "one or more, but not all, provinces," for example an amendment relating to provincial boundaries. ${ }^{78}$ It has been used seven times, more than any other amendment procedure, ${ }^{79}$ and not necessarily for insignificant matters. The final amendment procedure authorizes provinces to use the unilateral provincial amendment procedure to formally amend their own constitutions, though this requires only a simple majority of the provincial assembly ${ }^{80}$ Provinces may use this procedure to amend all matters related to provincial government that are not otherwise expressly assigned a higher amendment threshold. ${ }^{81}$

It would misunderstand the study of amendment difficulty to insist that the scores of all five amendment thresholds must be aggregated in order to arrive at the true measure of Canada's amendment difficulty. But it would also misunderstand amendment difficulty to measure only the highest threshold that is ever actually used in order to quantify Canada's constitutional rigidity. This approach would neglect the possibility that Canada's escalating amendment thresholds are less complementary than competing, and that the uncertainty they generate as to which amendment threshold ought to be used for a particular constitutional change is itself a feature that aggravates amendment difficulty. Indeed, we have recently seen evidence of political actors exploiting the Constitution's uncertainty as to which amendment rule applies to amendments on senatorial selection: political actors chose ultimately to pursue

Ibid, s 44 ("Subject to sections 41 and 42, Parliament may exclusively make laws amending the Constitution of Canada in relation to the executive government of Canada or the Senate and House of Commons").

75 Ibid.

76 See Fair Representation Act, SC 2011, c 26; Constitution Act, 1999 (Nunavut), SC 1998, c 15; Representation Act, 1985, SC 1986, c 8, s 3; see also Hogg, supra note 18 (cataloguing all constitutional amendments).

77 Constitution Act, 1982, supra note 8, s 43:

An amendment to the Constitution of Canada in relation to any provision that applies to one or more, but not all, provinces, including $(a)$ any alteration to boundaries between provinces, and (b) any amendment to any provision that relates to the use of the English or the French language within a province, may be made by proclamation issued by the Governor General under the Great Seal of Canada only where so authorized by resolutions of the Senate and House of Commons and Ibid. of the legislative assembly of each province to which the amendment applies.

See Constitution Amendment, 1998 (Newfoundland Act), SI/98-25, (1998) C Gaz II, online: <publications/gc.ca/gazette/ archives/p2/1998-01-14-x/pdf/g2-132xl.pdf>; Constitution Amendment, 2001 (Newfoundland and Labrador), SI/2001-117, (2001) C Gaz II, online: <publications.gc.ca/ gazette/archives/p2/2001-12-96-xl/pdf/g2-135x6.pdf>; Constitution Amendment Proclamation, 1997 (Quebec), SI/97-141; Constitution Amendment Proclamation, 1993 (Prince Edward Island), SI/94-50, (1994) C Gaz II, 2021; Constitution Amendment Proclamation, 1993 (New Brunswick Act), SI/93-54, (1993) C Gaz II, 1588; Constitution Amendment Proclamation, 1987 (Newfoundland Act), SI/88-11, (1988) C Gaz II, 887; see also Hogg, supra note 18, ch 1 at 1-7-1-8 (cataloguing all constitutional amendments).

Constitution Act, 1982, supra note 8, s 45 ("Subject to section 41, the legislature of each province may exclusively make laws amending the constitution of the province"). Ibid. 
the lower federal unilateral amendment threshold instead of the more onerous default multilateral amendment threshold. ${ }^{82}$ The very design of Canada's formal amendment rules may therefore discourage political actors from pursuing constitutional change through the normal channels of formal amendment and instead drive them to seek unconventional and irregular methods of informal amendment to update the Constitution. ${ }^{83}$ If, as I suspect, this is true, amendment complexity is a significant yet unquantifiable source of amendment difficulty that cannot be reflected in comparative studies of constitutional rigidity.

\section{EXTRA-TEXTUAL AMENDMENT RULES IN CANADA}

As onerous as Canada's formal amendment rules may be - and history has shown just how difficult they are to satisfy ${ }^{84}$ — the difficulty of formal amendment in Canada derives equally from sources external to those textual rules. Major constitutional amendments to fundamental features of the polity or Canadian identity, or to the framework of government or federal-provincial relations - and all other matters that Peter Russell defines generally as "mega constitutional politics" imposed by Supreme Court decisions, parliamentary and provincial statutes, and arguably also by constitutional convention. Many though not all of these extra-textual rules for formally amending the Constitution of Canada trace their impetus to legitimate concerns for protecting minority rights in connection with Quebec. ${ }^{86}$ When layered onto the existing formal amendment rules, these additional non-textual rules may well make major constitutional amendment impossible today in Canada.

See Albert, "Constructive Unamendability," supra note 23 at 211-15.

See Albert, "Constitutional Amendment by Stealth," supra note 23 (arguing that political actors have sought to circumvent the onerous formal amendment rules by creating a constitutional convention that will bind their successors functionally in much the same way as a formal amendment). A Supreme Court reference finally clarified which amendment threshold applies. See Reference re Senate Reform, 2014 SCC 32, [2014] 1 SCR 704 [Senate Reference].

84 For a discussion of the failures of the Meech Lake and Charlottetown Accords, see Michael B Stein, "Improving the Process of Constitutional Reform in Canada: Lessons from the Meech Lake and Charlottetown Constitutional Rounds" (1997) 30:2 Can J Political Science 307 at 315-29. We should not attribute the failure of the Meech Lake and Charlottetown Accords only to the difficulty of formal amendment in Canada. This is certainly a principal reason for the failure of both efforts, but we must distinguish the difficulty of formal amendment from the content of the amendment proposals themselves. The failure of both the Meech Lake and Charlottetown Accords is attributable in large part to the choice of political actors to present their proposed amendments in an omnibus package for wholesale constitutional renewal. The many components in each of the Accords made it difficult to secure widespread agreement across the country from the various political actors whose support was required under the rules of formal amendment. For one of the most useful explanations for the failure of the Charlottetown Accord, see Richard Johnston, "An Inverted Logroll: The Charlottetown Accord and the Referendum" (1993) 26:1 Political Science \& Politics 43 at 43:

The package Canadians rejected was formidably complex. It became so by a decade's accretion of elements, each calculated to appeal to, or to offset concessions to, groups excluded at an earlier stage - Quebec, the western provinces, and aboriginal peoples. Negotiators hoped that by 1992 they had finally found an equilibrium, a logroll sufficiently inclusive to survive referral to the people. Instead they seem to have gotten the logic of the logroll upside down: they may have overestimated both how much each group wanted what it got and how intensely some groups opposed key concessions to others. Russell, supra note 16 at 75 .

Indeed, the protection of minority rights is also in many instances the reason why this phenomenon arises elsewhere in the democratic world. I am grateful to Jim Repetti for drawing my attention to this important point. 


\section{A. Statutory Conditions}

Parliamentary and provincial statutes have exacerbated formal amendment difficulty. ${ }^{87} \mathrm{At}$ the federal level, Parliament passed the Regional Veto Law in $1996 .{ }^{88}$ The law, just an ordinary statute passed without recourse to the rules of formal amendment, made good on a federal promise to grant Quebec more powers, including a veto in major constitutional amendment. The promise was conditioned on Quebec rejecting secession in the 1995 referendum, ${ }^{89}$ which it did, though only by a slight margin. ${ }^{90}$ Under the Regional Veto Law, Quebec possesses a veto on major constitutional amendments proposed pursuant to the default multilateral amendment procedure in section 38. But the veto is not exclusive: the law grants the same veto power to the other regions of Canada, some of which are defined as provinces and others as provincial groupings: the Atlantic and Prairie provinces, Ontario, and British Columbia. ${ }^{91}$

The Regional Veto Law applies to major amendment proposals only under section 38 . The reason for its limited scope is that it is intended to fill a gap: section 38 is currently the only one of the five constitutionally-entrenched amendment thresholds implicating federalprovincial relations that does not currently authorize a provincial veto. ${ }^{92}$ The law does not expressly grant the designated regions a formal veto but it does give them a special protection that amounts to a functional veto: federal cabinet ministers may not propose a constitutional amendment under section 38 without first securing the consent of a majority of provinces - a majority that must include Quebec, Ontario, British Columbia, and at least two each of the Atlantic and Prairie provinces representing at least half of the regional population. ${ }^{93}$ Scholars have calculated that the provincial population distribution in the Prairie provinces results in granting an effective veto to Alberta as well. ${ }^{94}$ All other provinces beyond Quebec, Ontario, British Columbia, and Alberta may exercise a veto over major constitutional amendment proposals, but only in tandem with other regional allies that can combine with them to achieve a statutorily-required population threshold. ${ }^{95}$

The Regional Veto Law is an ordinary statute but its effect is extraordinary. It creates a significant barrier to formal amendment that now makes it even more unlikely that a major amendment will ever succeed. The prohibition on cabinet ministers proposing a section 38 amendment without provincial consent establishes a prior restraint not otherwise

Below, in connection with the Secession Reference, I also discuss the Clarity Act as an example of a parliamentary statute that has exacerbated amendment difficulty. See Section III.C, below.

An Act respecting constitutional amendments, SC 1996, c 1 [Regional Veto Law].

See Robert A Young, “Jean Chrétien's Québec Legacy: Coasting Then Stickhandling Hard” (2004) 9:1 Rev Const Stud 31 at 38-39.

The result of the referendum was close, with 2,362,648 voting to reject secession and 2,308,360 voting in favour. The participation rate was 93.52 percent. See Elections Quebec, "Référendums au Québec," online: <www.electionsquebec.qc.ca/francais/tableaux/referendums-quebec-8484.php>. Regional Veto Law, supra note 88, s 1(1).

Constitution Act, 1982, supra note 8, s 41 (requiring unanimous provincial agreement) and s 43 (requiring the agreement of affected province(s)) both effectively grant provinces a veto. Neither section 44 nor section 45 concern federal-provincial matters.

Regional Veto Law, supra note 88, s 1(1).

Andrew Heard \& Tim Swartz, "The Regional Veto Formula and Its Effects on Canada's Constitutional Amendment Process" (1997) 30:2 Can J Political Science 339 at 342-43.

See Greene, supra note 19 at 263-64. 
contemplated by the Constitution of Canada. ${ }^{96}$ In the past, the federal government could have introduced an amendment proposal in Parliament, and perhaps through debate and deliberation could have cobbled together the requisite parliamentary majority, and in doing so could have drawn provincial allies to its side as the amendment project grew in popularity. Now, however, the federal government must recruit provincial allies prior even to proposing an amendment in Parliament, reversing the order envisioned by the formal amendment rules and short-circuiting the amendment process before it ever begins. This statutory complication to the Constitution's formal amendment process has given rise to a non-trivial argument that the Regional Veto Law is unconstitutional. ${ }^{97}$

Provinces have likewise adopted their own laws that further constrain major constitutional amendment. These provincial laws now require either a binding or advisory province-wide referendum on any formal amendment for which provincial ratification is required. ${ }^{98}$ For example, Alberta requires a binding provincial referendum before the provincial assembly votes to ratify a major amendment requiring provincial ratification. ${ }^{99}$ British Columbia similarly prevents the provincial assembly from ratifying a formal amendment unless a binding province-wide referendum first authorizes the assembly to ratify it. ${ }^{100}$ Other provinces and territories, including New Brunswick, Saskatchewan, and Yukon, authorize but do not require their governments to hold binding referenda before voting to ratify or reject an amendment. ${ }^{101}$ Still others, like the Northwest Territories, Nunavut, Quebec, Prince Edward Island, and Newfoundland and Labrador, authorize but do not require an advisory referendum or plebiscite prior to a legislative vote on ratification. ${ }^{102}$

These provincial referenda laws are problematic for formal amendment in Canada. ${ }^{103}$ They too operate as a prior restraint to legislative decision-making. The Constitution requires no intervening decision or action between parliamentary proposal and provincial legislative vote. On the one hand, it is politically prudent for provincial political actors to consult their constituents on a major amendment proposal before they take action on it. On the other, the Constitution of Canada does not condition the validity of an amendment on these provincial

See David E Smith, “The Canadian Senate: What Is To Be Done?” in Christian Leuprecht \& Peter H Russell, eds, Essential Readings in Canadian Constitutional Politics (Toronto: University of Toronto Press, 2011) 43.

97 See Heard \& Swartz, supra note 94 at 340-41.

98 CES Franks, "A Continuing Canadian Conundrum: The Role of Parliament in Questions of National Unity and the Processes of Amending the Constitution" in J Peter Meekison, Hamish Telford \& Harvey Lazar, eds, The State of the Federation 2002: Reconsidering the Institution of Canadian Federalism (Montreal: McGill-Queen's University Press, 2004) 35 at 44.

$99 \quad$ Constitutional Referendum Act, RSA 2000, c C-25, ss 2(1), 4.

Constitutional Amendment Approval Act, RSBC 1996, c 67, s 1; Referendum Act, RSBC 1996, c 400, s 4 .

See Referendum Act, SNB 2011, c 23, ss 12-13 (establishing quorum requirement for vote to bind government); The Referendum and Plebiscite Act, SS 1990-91, c R-8.01, s 4 (establishing quorum and threshold requirements for vote to bind government); Public Government Act, SY 1992, c-10, s 7 (authorizing provincial assembly to decide ex ante whether referendum vote will bind government). See e.g. Consolidation of Plebiscite Act, RSNWT 19888, c P-8, s 5; Elections and Plebiscites Act, SNWT 2006, c 15, s 48; La Loi sur la consultation populaire, LRQ 2000, c C-64.1, s 7; Plebiscites Act, RSPEI 1988, c P-10, s 1. See also Elections Act, SNL 1992, c E-3.1, s 218 (authorizing non-binding plebiscite on federal amendment).

Citizens in the US have tried unsuccessfully to exercise the power to instruct their legislators how to vote on a formal amendment proposal. Courts have ruled these efforts unconstitutional for encroaching on the power of elected representatives to deliberate on the fate of an amendment. See Kenneth P Miller, Direct Democracy and the Courts (New York: Cambridge University Press, 2009) at 171-72; Kris W Kobach, "May 'We the People' Speak?: The Forgotten Role of Constituent Instructions in Amending the Constitution" (1999) 33:1 UC Davis L Rev 1 at 7-9. 
consultations, and the administration of a referendum or plebiscite only delays the provincial decision on a proposal which may be subject to a strict three-year time limit for ratification. ${ }^{104}$

Both of these extra-textual statutory conditions - conformity with the Regional Veto Law and with provincial referendum laws - impose formal amendment conditions over and above those required by Canada's formal amendment rules. Canada rejected an explicit provincial veto power for Quebec in both the Meech Lake and Charlottetown Accords. ${ }^{105}$ Yet the Regional Veto Law now grants to Quebec and to other provinces and regions just that. Moreover, although Canada has a long history of provincial referenda, none of the five formal amendment thresholds require or suggest a provincial referendum in either the proposal or ratification of a major constitutional amendment. Yet today many provincial referendum laws are now binding as a matter of statutory law on provincial political actors. The consequence of the Regional Veto Law and provincial referenda laws is that federal and provincial political actors must now govern themselves according to statutory rules as though they were binding as a constitutional matter.

This threatens to erode the distinction between the Constitution of Canada and a statute that is legally inferior to it. What makes the Constitution a constitution is that it enjoys a higher status relative to a statute, that it is more difficult to amend than a statute, and that a statute is derivative of the Constitution. ${ }^{106}$ These parliamentary and provincial statutes on constitutional amendment have effectively modified the Constitution's rules for formal amendment. They seem to aspire to constitutional or quasi-constitutional status insofar as they are meant to bind political actors in the process of constitutional amendment in the same way the Constitution does. The problem, however, is that these parliamentary and provincial statutes have not earned their special status through the channels the Constitution requires for achieving that constitutional status.

Returning to Lutz's index of amendment difficulty, it is hard to quantify how much more difficult the Regional Veto Law and the provincial laws make formal amendment in Canada. Lutz does not provide specifically for the kind of pre-initiation approval the Regional Veto Law requires, nor does he contemplate the possibility of pre-ratification provincial referenda, whether binding or consultative. But we may nonetheless approximate the relative value of each of these additional steps using Lutz's index of 68 possible actions that may in some combination be deployed in constitutional amendment. On his scale, the pre-initiation approval required by the Regional Veto Law is comparable to the requirement of multiple state legislative approval, which counts for $2.00 .{ }^{107}$ The pre-ratification provincial referenda are comparable to a series of popular referenda, valued on Lutz's scale at $1.50 .{ }^{108}$ When added to the score for amendment difficulty assigned to Canada's general amendment

See Constitution Act, 1982, supra note 8, s39(2) (creating a three-year time limit to ratify an amendment proposal).

105 See Meech Lake Accord, supra note 10; Charlottetown Accord, supra note 10.

106 Donald S Lutz, "Toward a Theory of Constitutional Amendment" in Levinson, Responding to Imperfection, supra note 22, 237 at 240; András Sajó, Limiting Government: An Introduction to Constitutionalism, english ed (Budapest: Central European University Press, 1999) at 39-40; Schneier, supra note 31 at 222 . 
threshold (4.50), these two new requirements raise Canada's score to 8.00, which exceeds the score for even the as yet unused national convention path (6.50) assigned to the US Constitution. ${ }^{109}$

\section{B. Popular EXPECTATIONS}

Quite apart from these legislative constraints on constitutional change, formal amendment must now arguably also conform to popular expectations of increased participation. ${ }^{10}$ It is possible, though far from clear, ${ }^{111}$ that there now exists a constitutional convention requiring a national consultative referendum before ratifying any major constitutional amendment. This convention, if one exists, derives from the decision to submit the 1992 Charlottetown Accord to a national referendum, even though the text of Canada's formal amendment rules did not then, nor do they now, require a referendum as a condition of successfully ratifying a constitutional amendment. ${ }^{112}$

Here, I am using "constitutional convention" in contrast to its use elsewhere in this article in connection with the as yet unused procedure for amending the US Constitution by "constitutional convention," a reference to an assembly of political actors that convenes to write or amend a constitution. In the sense in which I refer to the concept in connection with Canada, constitutional conventions are the body of understandings and norms that regulate the conduct of political actors. ${ }^{113}$ Common law courts generally do not enforce constitutional conventions but they do recognize them, as the Supreme Court of Canada did in the Patriation Reference when it recognized the existence of a convention of substantial provincial consent for major constitutional amendments. ${ }^{114}$ A constitutional convention is not a legal rule since it does not emerge from either the judicial or lawmaking process; it is better described as a rule of political morality because its content is determined by the action, agreement and the acquiescence of political actors. ${ }^{115}$ At bottom, a constitutional convention "ultimately reflect[s] what people do." ${ }^{\text {"16 }}$ Constitutional conventions bind political actors only inasmuch as they can neither emerge nor change by unilateral action; they require multilateral and cross-party ratification in order to arise and survive. ${ }^{117}$

The Charlottetown Accord was Canada's second major attempt, following the failed Meech Lake Accord in 1987, to address the matters left unresolved in the Constitution Act, 1982, such as the special status of Quebec, the rights of First Nations, and the modernization

110 See text accompanying notes 68-74, supra.

See Katherine Swinton, "Amending the Canadian Constitution: Lessons from Meech Lake" (1992) 42:2 UTLJ 139 at $167-68$.

111 I have elsewhere taken the position that we do not yet know whether such a constitutional convention has taken root. See Richard Albert, "The Conventions of Constitutional Amendment in Canada: Is There a Convention of Federal Referendal Consultation?," (Conference paper delivered at The Constitution of Conventions/Conventional Constitutionalism program, Trinity College Dublin, School of Law, 15 November 2014) [unpublished].

112 Constitution Act, 1982, supra note 8, ss 38-49.

AV Dicey, Introduction to the Study of the Law of the Constitution, 8th ed (London, UK: Macmillan, 1915) at xlix.

Reference re Resolution to Amend the Constitution, [1981] 1 SCR 753 [Patriation Reference]. Geoffrey Marshall, Constitutional Conventions: The Rules and Forms of Political Accountability (New York: Oxford University Press, 1984) at 216-17.

Ibid at 217.

Ibid. 
of national institutions. ${ }^{118}$ In response to the perception and indeed the reality that the Meech Lake Accord had been the result of a closed-door, back-room and elite-driven drafting process, ${ }^{119}$ political actors chose to open the Charlottetown process to public input, transparent deliberation, and ultimately national referendal consultation as a way to signal their commitment to make the new document Canadians' own. ${ }^{120}$ The national referendal consultation was authorized by a parliamentary law, the Referendum Act, which made it legally permissible and administratively possible to survey Canadians on "any question relating to the Constitution of Canada." 121 The referendum question was straightforward: "Do you agree that the Constitution of Canada should be renewed on the basis of the [Charlottetown Accord]?" 122 Voters rejected the Accord by 54.3 to 45.7 percent. $^{123}$

The extraordinary use of a national referendum in the Charlottetown process has prompted observers to suggest that future similar efforts should also incorporate a national referendum. ${ }^{124}$ The theory here is that the Charlottetown referendum has matured into a constitutional convention. The dominant view is that the Charlottetown referendum has set a "binding precedent" 125 that is "a fact of constitutional reform in Canada now" requiring public ratification for major, though not minor, constitutional reforms. ${ }^{126}$ The failure to poll voters in a referendum on any future constitutional reform on the scale of the Charlottetown Accord "is likely to be perceived as illegitimate." 127 The prevailing view is that the days of closed-door, back-room and elite-driven constitution-making and -changing are gone, and political actors must now attend to public inclusion through consultation and ratification when engaging in major efforts for constitutional renewal. ${ }^{128}$ There are some arguments to the contrary but they are squarely within the minority camp. For example, one scholar has

See Ronald L Watts, "Canada: Three Decades of Periodic Federal Crises" (1996) 17:4 Intl Political Science Rev 353 at 357.

119 See Peter H Russell, "Can the Canadians Be a Sovereign People?" (1991) 24:4 Can J Political Science 691 at $705-706$.

120 See Mary Dawson, "From the Backroom to the Front Line: Making Constitutional History or Encounters with the Constitution: Patriation, Meech Lake, and Charlottetown" (2012) 57:4 McGill LJ 955 at 983. Referendum Act, SC 1992, c 30, s 3(1).

Proclamation Directing a Referendum Relating to the Constitution of Canada, SI/92-180, (1992) C Gaz II, 3931.

See Elections Canada, The 1992 Federal Referendum : A Challenge Met (Ottawa: Office of the Chief Electoral Office, 1994) at 58, online: <www.elections.ca/res/rep/off/1992/1992_Referendum_Part_ 2_E.pdf $>$ [A Challenge Met].

See e.g., Dawson, supra note 120 at 997; Peter Leslie, "Canada: The Supreme Court Sets Rules for the Secession of Quebec" (1999) 29:2 Publius 135 at 142; Kenneth McRoberts, "After the Referendum: Canada with or without Quebec" in Kenneth McRoberts, ed, Beyond Quebec: Taking Stock of Canada (Montreal \& Kingston: McGill-Queen's University Press, 1995) 403 at 413; Matthew Mendelsohn, "Public Brokerage: Constitutional Reform and the Accommodation of Mass Publics" (2000) 33:2 Can J Political Science 245 at 251; Christa Scholtz, "Aboriginal Communities and the Charlottetown Accord: A Preliminary Analysis of Voting Returns" (Paper delivered at the Canadian Political Science Association Annual Meetings, Vancouver, June 2008) at 14, online: <www.cpsa-acsp.ca/papers2008/Scholtz. pdf>; Jeffrey Simpson, "The Referendum and Its Aftermath" in Kenneth McRoberts and Patrick J Monahan, eds, The Charlottetown Accord, the Referendum, and the Future of Canada (Toronto: University of Toronto Press, 1993) 193 at 193; Robert C Vipond, "Seeing Canada Through the Referendum: Still a House Divided" (1993) 23:3 Publius 39 at 54; José Woehrling, "La modification par convention constitutionnelle du mode de désignation des sénateurs canadiens"(2009) 39 RDUS 115 at 125 .

125 Roger Gibbins \& David Thomas, “Ten Lessons from the Referendum” (1992) 15:4 Can Parliamentary Rev 3 at 3 .

126 Kathy L Brock, "Learning from Failure: Lessons from Charlottetown" (1993) 4:2 Const Forum Const 29 at 32 .

127 R Kent Weaver, "Political Institutions and Conflict Management in Canada" (1995) 538 Annals American Academy Political \& Social Science 54 at 65.

128 Michael Adams, "The October 1992 Canadian Constitutional Referendum: The Socio-Political Context" in McRoberts \& Monahan, supra note 124, 185 at 192. 
argued that the lesson of the 1992 Charlottetown referendum is that it will be important to provide for popular involvement in some fashion in future efforts at major constitutional renewal though not necessarily in the form of referendal consultation. ${ }^{129}$ Another has suggested that the referendum may have created a precedent but that this precedent has not yet, nor might it ever become, a constitutional convention. ${ }^{130}$

Referendal consultation is of course not formally a condition of successful amendment in Canada. ${ }^{131}$ But if it is true that a convention has taken root now requiring a national referendum before a major amendment to the Constitution of Canada becomes valid, this will significantly increase Canada's formal amendment difficulty. Procedurally, this would mean that a major formal amendment pursuant to the unanimity threshold in section 41 would now require the following steps: (1) majority resolutions in both houses of Parliament; (2) separate referenda in the provinces and territories; ${ }^{132}$ and (3) unanimous legislative ratification by each of the provinces and territories. Under Lutz's index of amendment difficulty, this amendment procedure would score 6.50 , the sum of the value of Canada's unanimity threshold (5.00) and the use of a popular referendum for ratification (1.50). ${ }^{133}$ This score of amendment difficulty exceeds the score assigned to the US Constitution (5.10) and matches its score under the unused convention process (6.50).

There is a further point worth noting in connection with the new popular expectations of participation in constitutional amendment. In the aftermath of the Charlottetown referendum, the territories may now expect to play a formal role in a future major constitutional amendment. There were only two territories at the time of the Charlottetown referendum: the Northwest Territories and Yukon. Both participated in the referendum as partners equal to the provinces. ${ }^{134}$ The Referendum Act, pursuant to which the national referendal consultation on the Charlottetown Accord had been organized, authorized voters in all of Canada's electoral districts, whether in a province or a territory, to cast a ballot. ${ }^{135}$ Yet Canada's formal amendment rules made no provision then for territorial participation in constitutional amendment, nor do they now. Today, since 1999, Nunavut is Canada's third territory. ${ }^{136}$ The 1992 Charlottetown referendum may now be seen as a precedent that will in the future compel a continuing role for Canada's three territories in major constitutional amendments. This, too, will further complicate formal amendment in Canada.

\section{JUdicial STANDARDS}

In addition to new restrictions on formal amendment established by statute and possibly also by constitutional convention, the Supreme Court of Canada has further exacerbated

See Benoit Pelletier, "Reinventing Canada: The Challenges that Canada Faces in the Twenty-First Century" (2010) 4 JPPL 133 at 142.

130 See J Peter Meekison, "Canada's Quest for Constitutional Perfection" (1993) 4:2 Const Forum Const 55 at 56.

131 Constitution Act, 1982, supra note 8, ss 38-49.

132 It is not clear whether the referendum would be a single national one or a series of separate provincial and territorial ones.

Lutz, Constitutional Design, supra note 1 at 168.

See A Challenge Met, supra note 123 at 58.

Supra note 121, ss 3(1), 6(1).

See Constitution Act, 1999 (Nunavut), supra note 76. 
formal amendment difficulty in its interpretation of the Constitution of Canada. ${ }^{137}$ In both the Supreme Court Act Reference ${ }^{138}$ and the Secession Reference, ${ }^{139}$ the Court informally modified the textually entrenched requirements to amend the Constitution, and in so doing has not only made it more difficult to amend certain elements of the Constitution of Canada but, even more controversially, it may have also reserved to itself the power to resolve questions on the constitutionality of future amendments.

We begin with the Supreme Court Act Reference, a matter concerning which amendment threshold applies to amendments to the Supreme Court of Canada. ${ }^{140}$ The Court declared that its own essential features - specifically “the Court's jurisdiction as the final general court of appeal for Canada, including in matters of constitutional interpretation, and its independence" 141 — cannot be amended outside of the unanimity procedure. ${ }^{142}$ On the one hand, the Court's interpretation clarifies an uncertainty in the text: whether the Court's essential features are amendable pursuant either to the default multilateral amendment procedure or the unanimity procedure. On the other, the Court's interpretation is not mandated by the constitutional text, which states only that amendments to "the composition of the Supreme Court of Canada"143 shall require conformity with the unanimity threshold and that most other amendments to the Court must satisfy the lower default multilateral amendment procedure. ${ }^{144}$

In terms of amendment difficulty, the skeptical reading of the Supreme Court Act Reference suggests that the Court has made it even harder for political actors to make amendments to the Court's essential features. The strongest evidence of this newly-imposed hyper-difficulty of formal amendment is apparent in the Supreme Court Act Reference itself. The Court chose not to define these essential features with any precision, but rather only to identify generally what they include "at the very least," 145 and thereby reserve to itself the power to define further elements of its essential features in future matters. On this view, the Court has insulated itself from future formal amendments to features comprising not only its "composition" but also to its very nature as a judicial body. And where disputes arise as to whether an amendment concerns something requiring either the unanimity or default multilateral amendment procedure, the Court will be the one to decide which rule governs.

In contrast, the Supreme Court of the US has interpreted Article V to make its rules potentially more permissive. In Coleman v Miller, 307 US 433 at 452-55 (1939) [Coleman], the Court held that only Congress may determine what amounts to a reasonable time for states to ratify a duly proposed amendment and also that Congress' determination is a nonjusticiable political question. Whether the ruling is permissive or constraining turns on what period of time Congress understands to be "reasonable" for ratification. Coleman refined the Court's earlier judgment that states must ratify an amendment within a reasonable time after it is proposed by Congress, even though Article V does not specify any temporal limitation for ratification. See Dillon v Gloss, 256 US 368 at 375 (1921). Reference re Supreme Court Act, ss. 5 and 6, 2014 SCC 21, [2014] 1 SCR 433 at paras 90-105 [Supreme Court Act Reference]. Reference re Secession of Quebec, [1998] 2 SCR 217 [Secession Reference]. Supra note 138.

Ibid at para 94.

Ibid at paras $90-105$.

Constitution Act, 1982, supra note 8, s 41(d).

Ibid at s 42(d). A narrow class of amendments is still open to Parliament to make as ordinary legislation under the authority granted by the Constitution Act, 1867, supra note 36, s 101, which states that "The Parliament of Canada may, notwithstanding anything in this Act, from Time to Time provide for the Constitution, Maintenance, and Organization of a General Court of Appeal for Canada, and for the Establishment of any additional Courts for the better Administration of the Laws of Canada." 
As any institution would do in the interest of its self-preservation, the Court is likely to choose the harder amendment procedure for political actors to make changes to it.

The Secession Reference is similar in the sense that the Court reached beyond the text of the Constitution to uncover limitations on the power of formal amendment. The Court held that a formal amendment in connection with a provincial secession from Canada must be governed by the duty to negotiate as well as "underlying constitutional principles," including federalism, democracy, constitutionalism and the rule of law, and respect for minority rights. ${ }^{146}$ These principles are not stated in the text of Canada's formal amendment rules, nor are they expressly identified anywhere but in the Court's Reference as the principles that must govern negotiations on secession. Whether they correctly reflect Canada's constitutional traditions, and they very well might, is not the relevant question. ${ }^{147}$ It is rather that the Court departed from the Constitution's complete codification of formal amendment rules to entrench previously unwritten rules for formal amendment. A formal amendment in connection with secession must now respect these rules. ${ }^{148}$

Formal amendment in connection with secession must also respect the terms of the Clarity Act, which Parliament passed in 2000, two years after the Court's Secession Reference ${ }^{149}$ In its preamble, the Clarity Act communicates Parliament's interpretation of the Secession Reference, specifically that the Court "confirmed that, in Canada, the secession of a province, to be lawful would require an amendment to the Constitution of Canada" and that the negotiations leading to formalizing the secession of a province "would be governed by the principles of federalism, democracy, constitutionalism and the rule of law, and the protection of minorities." ${ }^{150}$ The Clarity Act creates rules for Parliament to deliberate on the referendum question to be posed to voters in a province. Those rules concern many aspects of a referendal vote on secession, including the timing of parliamentary deliberations, ${ }^{151}$ the types of questions to be posed in the referendum, ${ }^{152}$ the need to consider views in the province apart from those of the party proposing the referendum, ${ }^{153}$ and the criteria for evaluating the sufficiency of the expressed will to secede. ${ }^{154}$

Secession Reference, supra note 139 at paras 88-105.

There is an important body of scholarship on Canada's unwritten constitutional principles. See e.g. Sujit Choudhry \& Robert Howse, "Constitutional Theory and The Quebec Secession Reference" (2000) 13:2 Can JL \& Jur 143; Jean Leclair, "Canada's Unfathomable Unwritten Constitutional Principles” (2002) 27:2 Queen's LJ 389; Mark D Walters, "The Common Law Constitution in Canada: Return of lex non scripta as Fundamental Law" (2001) 51:2 UTLJ 91.

48 It is possible to read the Court in the Secession Reference as stating that political actors should respect the duty to negotiate and the underlying constitutional principles, but that the resolution of any dispute as to respecting these rules must occur in the political forum. For example, the Court wrote that " $[t]$ o the extent issues addressed in the course of negotiation are political, the courts, appreciating their proper role in the constitutional scheme, would have no supervisory role": Secession Reference, supra note 139 at para 153. But since Canada does not adhere to a political question doctrine, and since in any event it is difficult to separate law from politics, it is unlikely that the Court will not have a role in resolving disputes as to the constitutionality of a possible future secession. Indeed, the recent Senate Reference demonstrates the extent to which the Court will be involved, partly as a matter of necessity, in interpreting the scope and application of Canada's formal amendment rules. See Senate Reference, supra note 83.

An Act to give effect to the requirement for clarity as set out in the opinion of the Supreme Court of Canada in the Quebec Secession Reference, SC 2000, c 26 [Clarity Act].

Ibid, preamble.

Ibid, ss 1(1)-(2).

Ibid, s 1(4).

Ibid, ss 1(5), 2(3).

Ibid, s 2(1)-(2). 
Like the Regional Veto Law, the Clarity Act is an ordinary statute passed without recourse to the rules of formal amendment. Yet its effect extends further than an ordinary statute because it is designed to impose constraints on constitutional amendment beyond those entrenched in the constitutional text. The most important constraint in this respect is the Clarity Act's prohibition on any Minister of the Crown proposing a constitutional amendment to authorize the secession of a province unless the Government of Canada has first negotiated a number of items in connection with the planned secession, including the division of assets and liabilities, provincial borders, the interests and claims of First Nations, and the protection of minority rights. ${ }^{155}$ These are of course reasonable expectations from political actors engaged in negotiating a provincial secession. But it is important to recognize that these changes to the Constitution of Canada - how it can be amended, who can amend it and when, and what rules limit the amendment process itself — have been made by an ordinary statute. The Clarity Act must be understood for what it is: an ordinary statute, like the Regional Veto Law, ${ }^{156}$ that has sought to informally modify the Constitution's formal amendment rules.

There is no verifiable way to quantify the difficulty that these new interpretive standards now add to the larger scheme of formal amendment in Canada. They will certainly make it more difficult to amend matters related to the Court and to provincial secession. The suitability of the amendment procedures and the constitutionality of an amendment itself will now be judged by the Court as the ultimate arbiter of the constitutionality of amendments in these domains, and perhaps in others still to be identified by the Court itself. ${ }^{157}$ It is of course not unusual in a constitutional democracy for a court to possess the power to declare that a constitutional amendment is unconstitutional. We have seen courts in Germany, India, South Africa, and Turkey among others assert variations on this power, ${ }^{158}$ and courts around the world are trending toward adopting a doctrine of unconstitutional constitutional amendment. ${ }^{159}$ But it nonetheless raises questions of democratic legitimacy for the Court to invalidate an amendment that has satisfied all of the formal strictures entrenched in the Constitution, particularly were the Court relies on unwritten principles that can be identified and interpreted by the Court alone. ${ }^{160}$

\section{Canadian Constitutionalism and Formal Amendment}

Amending the Constitution of Canada is therefore much harder than its text suggests. The dialogic interactions of Canadian political actors have given rise to extra-textual rules over

Ibid, s 3(2).

One could argue that the Regional Veto Law and the Clarity Act are examples of a "superstatute," a law that has been passed through the ordinary lawmaking process but that has achieved quasi-constitutional status in light of its high salience in public life or its importance to the framework of government. The effect of a superstatute is to informally modify the rules and expectations set by the master-text constitution. See William N Eskridge, Jr \& John Ferejohn, "Super-Statutes" (2001) 50:5 Duke LJ 1215 at $1230-31$.

For an effort at explaining how Canadian courts could review the constitutionality of constitutional amendments, see Richard Albert, "The Theory and Doctrine of Unconstitutional Constitutional Amendment in Canada" 41 Queen's LJ [forthcoming in 2016].

See Richard Albert, "Nonconstitutional Amendments" (2009) 22:1 Can JL \& Jur 5 at 21-31.

See Yaniv Roznai, "Unconstitutional Constitutional Amendments-The Migration and Success of a Constitutional Idea" (2013) 61:3 Am J Comp L 657 at 676-713.

See Joel I Colón-Ríos, Weak Constitutionalism: Democratic legitimacy and the question of constituent power (Abingdon: Routledge, 2012) at 67. 
and above the already onerous formal amendment rules entrenched in the Constitution Act, 1982. ${ }^{161}$ These formal and extra-textual rules make the Constitution exceedingly rigid, perhaps even more resistant to alteration than the US Constitution, long believed by scholars to be among the world's most difficult democratic constitutions to amend. ${ }^{162}$ The nearimpossibility of formal amendment raises serious problems related both to participatory democracy as well as the legitimacy of extra-textual limitations on the amendment power. In this Part, I will suggest that extreme amendment difficulty is problematic because it burdens the democratic and deliberative purposes of formal amendment. I will also suggest that the extra-textual foundations of Canada's extreme amendment difficulty risk undermining Canadian constitutionalism and the rule of law.

\section{A. DEMOCRACY AND AMENDMENT}

Where a constitution is difficult to amend, the consequence is to barricade the provisions entrenched by the authoring generation. Amendment difficulty privileges the status quo and reinforces the values and vision of those whose voice prevailed in creating the constitution. Constitutional designers who are either too sure of themselves or too distrusting of their successors therefore sometimes choose to entrench provisions against formal amendment altogether, making them formally unamendable. ${ }^{163}$ A constitutional provision is unamendable where no measure of legislative or popular agreement, not even unanimity, is sufficient to authorize a formal amendment to it. ${ }^{164}$ For example, the German Basic Law makes "human dignity" formally unamendable, ${ }^{165}$ the Italian Constitution declares that republicanism "shall not be a matter for constitutional amendment," 166 and the Turkish Constitution states that secularism "shall not be amended, nor shall [its] amendment be proposed." 167 Constitutional designers entrench unamendable provisions like these often to commit their successors to respecting the values they have chosen to privilege with this design strategy. ${ }^{168}$

Unamendability has become an increasingly common feature in modern constitutions. Over half of the world's new constitutions from 1989 to 2013 entrenched an unamendable provision, as compared to roughly one quarter of those constitutions enacted between 1945 and 1988, and fewer than 1 in 5 of all constitutions created between 1789 and $1944 .{ }^{169}$ But unamendability need not be formalized in the constitutional text. It can arise informally where the political climate makes it practically unlikely, though nonetheless always theoretically possible, to gather the supermajorities required to formally amend the

For a discussion of what these rules require, see Part I.C, above.

See text accompanying notes 1-7, supra.

Sanford Levinson, "Designing an Amendment Process" in John Ferejohn, Jack N Rakove \& Jonathan Riley, eds, Constitutional Culture and Democratic Rule (Cambridge, UK: Cambridge University Press, 2001) 271 at 276 .

Formal unamendability is of course not resistant to revolution or the design of a new constitutional order altogether: see John R Vile, "Limitations on the Constitutional Amending Process" (1985) 2:2 Const Commentary 373 at 375 .

Grundgesetz für dre Bundersrepublik Deutschland (Basic Law), May 23, 1949, BGB1 I (Ger), arts 1(1), 79(3), translated by Christian Tomusohat \& David P Currie, online: <www.btg-bestellservice.de/pdf/ 80201000.pdf>.

Art 139 Costituzione (It).

Constitution of the Republic of Turkey, pt I, art 4 (1982).

See Richard Albert, "Constitutional Handcuffs" (2010) 42:3 Ariz St LJ 663 at 678-85.

See Yaniv Roznai, Unconstitutional Constitutional Amendments: A Study of the Nature and Limits of Constitutional Amendment Powers (PhD Thesis, London School of Economics Department of Law, 2014) at 28 [unpublished]. 
constitution. This kind of "constructive" unamendability derives from deep divisions among political actors, an inhospitable political climate for formal amendment, and alternatively or in addition from the structural design of the constitution, each of which can lead to stalemate in formal amendment. ${ }^{170}$ Scholars have described formal amendment in Canada as virtually impossible for those reasons. ${ }^{171}$ Even excepting the extra-textual restrictions that have been imposed on formal amendment in Canada, the Constitution of Canada as written is today constructively unamendable on matters requiring the default of unanimity procedure. This constructive unamendability entrenches the vision of the Constitution's authors more rigidly than even the authors themselves may have imagined possible.

The same critiques apply equally to formal as to constructive unamendability. The result in either case is to take a given constitutional provision off the amendment table, and to thereby place it beyond the reach of political actors. This has more than theoretical costs. Disabling the formal amendment process has real consequences for political actors and the people they represent because it prevents anyone but the drafting generation from seeing its values reflected in the text of the constitution. This manifests itself in several ways. Unamendability denies political actors and the people the capacity for deliberative engagement with the constitutional text and the possibility of adapting the text to modern sensibilities. ${ }^{172}$ Unamendability as a constitutional form moreover overlooks the possibility that the constitution as designed and as interpreted may be imperfect or even unjust. ${ }^{173} \mathrm{No}$ constitution illustrates this point more clearly than the US Constitution, which originally entrenched the slave trade as temporarily formally unamendable until 1808, a full generation after the Constitution's coming-into-force in $1789 .{ }^{174}$ Had the slave trade been indefinitely formally unamendable, American history may have unfolded differently.

\section{B. The Weakening OF Writtenness}

Unamendability has undermined the democratic foundations of formal amendment. When formal amendment rules first appeared in constitutions, their purpose was to make possible an informed and deliberative judgment to improve the text when time and experience revealed faults. ${ }^{175}$ The very nature of a mature polity governed by a written document required then and still today that political actors have the capacity to keep the constitutional text aligned with the evolving norms and views of the people it is intended to govern. ${ }^{176}$ Unamendability has since eroded some of the envisioned virtue of formal amendment rules,

See Albert, "Constructive Unamendability," supra note 23 at 194-96.

See e.g. Bettina Petersohn, "Constitutional Reform and Federal Dynamics: Causes and Effects" in Arthur Benz \& Jörg Broschek, eds, Federal Dynamics: Continuity, Change, and the Varieties of Federalism (Oxford: Oxford University Press, 2013) 297 at 316; Christopher P Manfredi \& Michael Lusztig, "Why do Formal Amendments Fail? An Institutional Design Analysis" (1998) 50:3 World Politics 377 at 380; Michael Lusztig, "Constitutional Paralysis: Why Canadian Constitutional Initiatives Are Doomed to Fail" (1994) 27:4 Can J Political Science 747 at 748.

Melissa Schwartzberg, Democracy and Legal Change (Cambridge, UK: Cambridge University Press, 2007) at 204-205.

Ibid at 202-203.

US Const art V.

See John R Vile, The Constitutional Amending Process in American Political Thought (New York: Praeger, 1992) at 23-38.

Lester Bernhardt Orfield, The Amending of the Federal Constitution (Ann Arbor: University of Michigan Press, 1942) at 1. 
disabling them, if even as to only a discrete range of constitutional provisions, and denying them their intended function.

There is another more important sense in which amendment difficulty specifically in Canada has weakened writtenness. Canada's formal amendment rules were entrenched as a complete code for altering the constitutional text, with each of the five amendment thresholds designed to occupy the entire universe of amendment possibilities. But the cluster of extratextual restrictions imposed by parliamentary and provincial statutes, judicial decisions, and constitutional conventions has transformed the written Constitution into an incomplete code for the accomplishment of a task that is by definition rooted in textual authority.

Inquiring into the history of the design of Canada's formal amendment rules illuminates their intended purpose. Of course, we should not today feel bound by the motivations of the authoring generation but it is nonetheless important to understand the objectives for which Canada's formal amendment rules were created to begin with. At Confederation, the British North America Act, 1867 (since renamed the Constitution Act, 1867), ${ }^{177}$ authorized only the Parliament of the UK to formally amend the Constitution of Canada, ${ }^{178}$ with the exception that an individual province could amend its own provincial constitution. ${ }^{179}$ The Parliament of Canada was ultimately given a narrow amendment power comparable to the narrow provincial authority in formal amendment: Parliament became authorized to amend only those purely federal subjects under Parliament's purview, ${ }^{180}$ a power analogous to a province's authority to amend only those subjects of purely provincial concern within its jurisdiction. Over time, there developed an expectation that all other amendments were possible only by recourse to the Parliament of the UK at the request of a joint resolution of the House of Commons and the Senate. ${ }^{181}$

An important question arose, however, as to what degree of provincial consent was needed for an amendment affecting federal-provincial relations. Political actors disagreed on this question, and it was not until the Patriation Reference that the Supreme Court helped accelerate a resolution to the impasse. The Court recognized that a convention of substantial provincial consent to amendments on federal-provincial relations had emerged over the many decades of constitutional change without any textual referent establishing any particular amendment rule. ${ }^{182}$ An evaluation of prior constitutional practice had shown that, between Confederation and 1964, there had been sixteen instances of formal amendment to the Constitution of Canada, ten of which had been exclusively federal in nature. ${ }^{183}$ As to the remaining six, each affected federal-provincial relations, and in all but one instance the federal government had consulted with the concerned provinces and secured their unanimous

Constitution Act, 1867, supra note 36.

Peter W Hogg, "Constitutional Reform in Canada - A Comment on the Canadian Constitutional Crisis" (1980) 6:2 Yale Studies World Public Order 285 at 287-88.

Constitution Act, 1867, supra note 36, s 92(1), as repealed by Constitution Act, 1982, supra note 8, s 53(1).

British North America (No 2) Act (UK), 12, 13 \& 14 Geo VI, c 81, s 1.

William R Lederman, “Canadian Constitutional Amending Procedures: 1867-1982” (1984) 32:2 Am J Comp L 339 at 340.

Patriation Reference, supra note 114 at 875.

Guy Favreau, The Amendment of the Constitution of Canada (Ottawa: Queen's Printer, 1965) at 16. 
agreement. ${ }^{184}$ The Court therefore held that political actors were constrained as a matter of convention to respect the established norm of constitutional practice. ${ }^{185}$

When political actors ultimately agreed to the formal amendment rules now entrenched in the Constitution Act, 1982, they had been repeating an old exercise, which had failed each time before, to create procedures for formal amendments that would concern neither the provinces alone nor the federal government alone. A study of the interprovincial and parliamentary conference debates on the design of Canada's formal amendment rules from the 1920s through their eventual entrenchment in 1982 demonstrates that the objective in creating a home-grown framework of formal amendment rules was to create amendment procedures that would cover every aspect of formal constitutional change. From procedures concerning amendments to only intraprovincial matters, to those concerning matters purely internal to the operation of Parliament, and to procedures requiring varying degrees of interprovincial negotiation - a central purpose for creating Canada's escalating structure of formal amendment was to assign every conceivable category of amendment to a specific formal amendment procedure. The reason was plain: to in the future avert the possibility of ambiguity and stalemate that had led to the Patriation Reference. ${ }^{186}$ I am currently developing a more detailed study of the history of the design of Canada's formal amendment rules in which I will demonstrate this point with reference to archival records of the interprovincial and parliamentary conference debates that led to the adoption of the formal amendment rules. $^{187}$

When read in light of this history of the design of Canada's formal amendment rules, these new extra-textual restrictions imposed by judicial interpretation, by parliamentary and provincial as well as territorial laws, and by constitutional convention undermine the entrenchment of Canada's escalating structure of formal amendment rules and indeed the very purpose of writtenness. It is of course true that no constitution is itself as a matter of fact, nor can it ever be as a matter of reasonable self-description, an exhaustive catalogue of all applicable rules. ${ }^{188}$ Written constitutions must be supplemented by unwritten constitutional norms that fill some of the gaps in the constitutional text or that are so fundamental that they need not be entrenched in writing. ${ }^{189}$ These norms operate as obligations that are unreflected in the constitutional text but they are nonetheless still valid. Conventional obligations develop where there are precedents that validate the obligation,

Ibid at $12-16$.

Patriation Reference, supra note 114 at 905.

Ironically, of course, the design of Canada's formal amendment rules has not resolved all disagreement. Political actors continue to disagree about the meaning and proper use of the various procedures for formal amendment. The controversy leading to the Senate Reference, and its aftermath, is a case in point: see Senate Reference, supra note 83.

My research relies on a series of historical documents including: Parliament, Dominion-Provincial Conference, "Precis of Discussions: Dominion-Provincial Conference November 3 to 10, 1927" in Sessional Papers No 69 (1928); House of Commons, Special Committee on British North America Act Proceedings and Evidence and Report (Ottawa: King's Printer, 1935) at iv; Constitutional Conference of Federal and Provincial Governments, Report of Proceedings (Ottawa: 10-12 January 1950) at 10 (comments of Louis St Laurent); Favreau, supra note 183, at 38-39; Constitutional Conference, Third Working Session: Statement of Conclusions (Ottawa: 8-9 February 1971); Secretariat of the Constitutional Conference, Constitutional Conference (Victoria: 14-16 June 1971); Federal-Provincial Conference of First Ministers on the Constitution, Doc 800-14/02 (Ottawa: 8-13 September 1980).

See generally John Gardner, "Can There Be a Written Constitution" in Leslie Green \& Brian Leiter, eds, Oxford Studies in Philosophy of Law (Oxford: Oxford University Press, 2011) vol 1 at 162 (exploring the limits of writtenness).

See Albert, "Constitutional Desuetude," supra note 23 at 654-56. 
where political actors feel themselves bound by those precedents, and where there is a valid reason motivating political actors to respect the precedent. ${ }^{190}$ This much is uncontroversial, and it helps explain why political actors obey rules that exist outside of the master-text constitution.

\section{Formal Amendment Rules AND THE VALUE OF WRITTENNESS}

Formal amendment rules are different from other entrenched constitutional rules. Formal amendment rules constitute the "supreme criterion of law" in regimes where a new provision adopted according to formal procedures and subsequently entrenched in the master-text constitution takes priority over all prior law to the extent of any discovered or intended incompatibility. ${ }^{191}$ As the gatekeepers to the constitutional text, formal amendment rules police both the "rules of the game in a society" as well as the "rules for changing the rules." ${ }^{192}$ No part of a constitution is more important than formal amendment rules, ${ }^{193}$ largely because they "define the conditions under which all other constitutional norms may be legally displaced." 194 The very entrenchment and authorized use of formal amendment rules reflect the core democratic values we associate with the rule of law, namely transparency, predictability and accountability. ${ }^{195}$ Only where the law and the rules by which it is changed are known and publicized, stable and precise, and moreover created in a monitorable process according to pre-established rules may we cultivate a constitutional culture where the text is perceived as mattering and also actually matters. ${ }^{196}$

On this view, extra-textual restrictions on formal amendment in Canada are problematic for the rule of law. Their effect, functionally though not in form, is to alter the requirements to formally amend the Constitution of Canada. This is problematic in two principal ways. First, it creates uncertainty where none once existed: the five detailed rules of formal amendment are now revealed as stating only the necessary but insufficient conditions to amend the Constitution, contrary to the very purpose of entrenching formal amendment rules to begin with. Formal amendment rules are supposed to constitute a complete code for altering the constitutional text. Yet in Canada they have been modified extra-textually to require criteria unknown and unspecified in the constitutional text, thereby changing the terms of the bargain struck among the parties to the Constitution Act, 1982 in defiance of our expectation of transparent and collective authorship that writtenness entails. ${ }^{197}$ That today these extra-textual restrictions have changed the rules of formal amendment suggests that

Ivor Jennings, The Law and The Constitution, 5th ed (London, UK: University of London Press, 1967) at $126-27$.

Kent Greenawalt, "The Rule of Recognition and the Constitution" (1987) 85:4 Mich L Rev 621 at 632. Bjørn Erik Rasch \& Roger D Congleton, "Amendment Procedures and Constitutional Stability" in Roger D Congleton \& Birgitta Swedenborg, eds, Democratic Constitutional Design and Public Policy: Analysis and Evidence (Cambridge: MIT Press, 2006) 319 at 319, 321 [emphasis added].

See Albert, "Amending Constitutional Amendment Rules," supra note 23.

Akhil Reed Amar, "The Consent of the Governed: Constitutional Amendment Outside Article V" (1994) 94:2 Colum L Rev 457 at 461.

Joseph Raz, The Authority of Law: Essays on Law and Morality, 2nd ed (Oxford: Oxford University Press, 2009) at 214-19.

Brannon P Denning, "Means to Amend: Theories of Constitutional Change" (1997) 65:1 Tenn L Rev 155 at 237.

See Reva B Siegel, "Text in Contest: Gender and the Constitution from a Social Movement Perspective" (2001) 150:1 U Pa L Rev 297 at 314-15. 
more, fewer, or different restrictions may be established by the future judgments of political actors, thereby breeding doubt about the text and whether it may be read as expressing a reliable standard for the conduct of political actors in the process of formal amendment.

Second, these extra-textual limits on formal amendment result in changing Canada's formal amendment rules themselves without meeting the required threshold for their amendment. Section 41 of the Constitution Act, 1982 mandates that "any amendment" to the requirements of formal amendment must fulfill the requirements of the unanimity procedure. ${ }^{198}$ One could certainly argue that these extra-textual restrictions do not constitute an "amendment" to Canada's formal amendment rules insofar as they do not alter the text of the Constitution. On narrow textualist grounds, this would defeat the claim that these new extra-textual limits are invalid unless created by formal amendment. But it would fail to appreciate the extent to which political actors may perceive these new extra-textual restrictions as binding upon them and their successors, in which case there is little functional difference between the formal and informal amendment of formal amendment rules.

The better argument, in my view, is that these extra-textual restrictions constitute modifications to Canada's formal amendment rules. The democratic values of the rule of law - transparency, predictability, and accountability - counsel that political actors should either incorporate these restrictions into the constitutional text by validating them through the procedures required by section 41 or alternatively declare that those extra-textual rules are not binding upon them or their successors in future attempts to formally amend the Constitution of Canada. Both options are suboptimal, the former with respect to the likelihood of formal amendment and the latter because political actors are unlikely to find it profitable to declare those rules non-binding. The first option - formally amending Canada's formal amendment rules — is off the table given the difficulty of formal amendment today.

The alternative, then, is for political actors to treat these new extra-textual restrictions as either inapplicable or illegitimate. This would mean interpreting the Charlottetown referendal experience as only informing but not binding future efforts at major constitutional amendment. It would also mean rethinking the validity of the Regional Veto Law, the Clarity Act, as well as the provincial and territorial laws on referenda or plebiscites. The Court's recent Senate Reference actually suggests that these laws are impermissible: if, as the Court held, Parliament cannot change the method of senatorial selection by ordinary legislation, ${ }^{199}$ then on what basis may Parliament or a provincial or territorial legislature change the law governing formal amendment in Canada by ordinary legislation? The reasonable answer is that ordinary legislative attempts to circumvent the formal amendment rules entrenched in the Constitution of Canada should be treated as equally invalid. As to the Court's own new restrictive interpretation of Canada's formal amendment rules, it is unclear what recourse political actors have short of questioning the legitimacy of the Court's role in informally modifying the textually-entrenched standard required for formal amendment. 


\section{CONCLUSION}

Canada's already onerous formal amendment rules have been modified extra-textually by judicial interpretation, parliamentary and provincial as well as territorial laws, and arguably also by constitutional convention. The result has been to make a rigid constitution even more rigid, and perhaps even to elevate the Constitution of Canada above the US Constitution on the scale of amendment difficulty for major constitutional amendments. But measuring amendment difficulty is itself a difficult task that should include a variable to measure the culture of amendment in a given regime, something that is hard not only to measure but also to identify. ${ }^{200}$

Perhaps the rigidity of the Constitution of Canada is a feature not a flaw. On this view, the authors of the Constitution Act, 1982 made it difficult to achieve the necessary majorities for a formal amendment with good reason: to protect the institutions of government from the vagaries of the political process. By requiring that certain constitutional changes occur only with recourse to the high threshold of the default multilateral amendment procedure or the higher threshold of the unanimity procedure, the Constitution's formal amendment rules ensure that any major amendment reflects the considered judgment of the democratic community. The difficulty of formal amendment in Canada is therefore intended to verify the commitment of political actors and the people to transforming the Constitution of Canada into something other than what the authoring generation envisioned.

The problem, however, arises where political actors change the rules of formal amendment in ways that the formal amendment rules do not authorize. Whether these informal changes to formal amendment rules make the Constitution of Canada harder or easier to amend is not the point: it is that these informal changes to formal amendment rules do not play by the rules of the game for constitutional change. It is no justification of these extra-textual restrictions that they are innovative mechanisms that help political actors overcome the intransigence of the formal amendment process. Political actors are bound by the constitutional text to work within its established framework, not to find ways to circumvent it.

It is true that the Constitution of Canada is different in an important respect from the US Constitution: it is not a master-text constitution. The Constitution of Canada is a partially codified and uncodified document that admits of many idiosyncrasies. ${ }^{201}$ Perhaps none better reflects the uniqueness of the Constitution of Canada than the phenomenon of constitutional desuetude, an informal method of constitutional change that occurs where an entrenched provision over time becomes unuseable as a matter of political reality, though not as a matter of law. Examples include the textually entrenched disallowance and reservation powers, and perhaps also the notwithstanding clause. ${ }^{202}$ One might well argue that it is accordingly not problematic for the theory and practice of constitutionalism in Canada for political actors to

The best effort thus far to begin to identify "amendment culture" and its consequences in Canada appears in Jamie Cameron, "Rules, Legitimacy and Amendment Constitutionalism in Canada" [unpublished draft on file with author].

201

Nonetheless, the written parts of the constitutions of Canada and the US have both changed informally, without a new writing in the constitutional text, as a result of changes in constitutional convention. I explore and evaluate these unwritten constitutional change elsewhere: see Richard Albert, "How Unwritten Constitutional Norms Change Written Constitutions" 38 Dublin ULJ [forthcoming in 2015]. Albert, "Constitutional Desuetude," supra note 23 at 656-73. 
graft conceptually onto the constitutional text the kinds of extra-textual restrictions on the amendment power that have occurred by judicial interpretation, statute, and convention. After all, as Hans Kelsen observed about the modalities of constitutional change, "[t]here is no legal possibility of preventing a constitution from being modified by way of custom, even if the constitution has the character of statutory law, if it is a so-called 'written' constitution."203

But what is ultimately lost in leaving these extra-textual restrictions uncodified are the three core promises of written constitutionalism: fair notice about the rules by which political actors are to exercise official authority, a textual referent for the people to hold accountable their representatives and for the political class to hold itself to account, and symmetry between the expectations the constitutional text creates and the outcomes it generates. Codified constitutions of course have many functions: they structure the framework of government, they entrench rights and freedoms, and they express values. But the principal function of a codified constitution, in my view, is to create rules by which political actors discharge their official duties. Those rules must always be changeable, but they must change according to the rules prescribed for that purpose. Where those rules change in ways not prescribed, the risk is to undermine the legal, political, and indeed the moral capacity of the constitutional text to structure and constrain the conduct of political actors. 
This page is blank - do not strip it in 